\title{
TRADISI RUWAH DESA DAN IMPLIKASINYA TERHADAP PENGETAHUAN TAUHID MASYARAKAT DUSUN NGENDUT KESAMBEN NGORO JOMBANG
}

\author{
Nurul Indana \\ Sekolah Tinggi Ilmu Tarbiyah Al Urwatul Wutsqo Jombang \\ nurulindana91@gmail.com \\ M. Aman Makmun \\ Sekolah Tinggi Ilmu Tarbiyah Al Urwatul Wutsqo Jombang \\ mamanmamun3@gmail.com

\section{Siti Machmudah} \\ Sekolah Tinggi Ilmu Tarbiyah Al Urwatul Wutsqo Jombang \\ opsidah99@gmail.com
}

\begin{abstract}
Abstrak: Tradition is everything inherited from the past and present. Some historical records write how the traditions currently preserved by the community are the result of a mixture of past cultures, cultures of the major religions that dominated the beliefs of Javanese, Hindu-Buddhist societies. One of them is the "ruwab" tradition. In the "ruwah" tradition it teaches the importance of cooperation, mutual cooperation and sharing with others. The village's "ruwab" tradition which is the pride of the Ngendut hamlet residents is a tradition as gratitude and offering to nature, god especially to the ghost of the village guard who have given an abundance of agricultural produce, health and prosperity. The village "ruwab" tradition begins with Tablil and Yasin the night before, then the next day it is opened with a feast which is held in the village's grave, followed by a shadow
\end{abstract}


puppet show as the core of the "ruwab" village tradition which is performed at the funeral as well. The village "ruwab" program was closed with a shadow puppet show at night, which was held in front of the hamlet head's house or at the house of another resident in accordance with the agreement. The Ngendut hamlet community is often called the abangan community whose connotations refer to people with low religious knowledge and often practice contrary to religion. Among the people who worship and enjoy the blessings of the ghosts of village guards, minority groups emerge who are trying to change traditional practices to be more Islamic. Although faced with opponents from the majority group, these people remain in the position and try to take adaptive steps. This minority group's struggle began to show the results today, albeit on a small scale.

Kata Kunci: Village Ruwah Traditions, Implications for Monotheism Knowledge

\section{Pendahuluan}

Masyarakat Jawa telah mengembangkan sebuah budaya literel dan religius yang canggih serta diperintah oleh kaum elite yang berpikiran cukup maju, jauh sebelum Islam tercatat muncul untuk pertama kalinya dalam masyarakat Jawa pada abad ke 14. Peradaban yang lebih tua diilhami gagasan-gagasan Hindu serta Budhis yang meninggalkan beragam warisan ${ }^{1}$. Peninggalan-peninggalan ini bermacam-macam bentuk, mulai dari seni rupa, arsitektur, sampai pada pemikiran dan tradisi.

Nama Jawa yang disematkan dalam pulau terpadat di Indonesia ini memiliki sejarah yang cukup menarik. Pulau dengan titik terjauh lebih dari $1.200 \mathrm{~km}$ dan lebar $500 \mathrm{~km}$ ini memiliki beberapa pendapat yang menyatakan asal mula penamaan pulau ini. Menurut Babad Tanah Jawa dan sumber kronik kuno, Jawa dulu disebut dengan "Nusa Kendang." Daratan yang menjadi bagian yang menyatu dengan semenanjung India ${ }^{2}$

Sedang dalam kitab Tantu Penggelaran dan Kitab Purwajawa Jawa (Java), atau sebutan lain Djawa Dwipa atau Djawi, berasal dari kata "jawajut" yang berarti "padi" atau "pulau padi". Secara resmi yang

\footnotetext{
${ }^{1}$ M.C. Ricklefs, Mengislamkan Jawa: Sejarah Islamisasi di Jawa dan Penentangnya dari 1930 sampai Sekarang, (Jakarta: PT Serambi Ilmu Semesta, 2013), 29.

2 Suyono, Dunia Mistik Orang Jawa (Jogjakarta: PT. LkiS, 2009), 5.
} 
menyematkan nama Jawa adalah Aji Saka. Ia juga yang menetapkan abjad Hanacaraka, selain menetapkan Kalender Saka terhitung sejak kedatangannya di Tanah Jawa untuk kemudian menjadi tonggak dimulainya sejarah Jawa. ${ }^{3}$

Tidak ada bukti otentik yang menjelaskan dari mana ras Jawa berasal. Namun terdapat beberapa pendapat yang merujuk pada keyakinan yang dipeluk masyarakat Jawa kala itu, banyak yang menyakini bahwa penduduk pribumi Jawa didominasi oleh pendatang dari India yang kemudian bercampur dengan etnis minoritas Persia dan etnis-etnis lain yang menciptakan keberagaman etnis dipulau Jawa. Saat itu Jawa dijadikan tempat migrasi bangsa India dan tempat pelarian kelompok masyarakat yang tersisih akibat konflik agama.

Pendatang yang membawa ajaran Hindu ini dikenal dengan sebutan Brahmanisme. Tak lama setelah ajaran Brahmanisme, muncul pula ajaran Budhisme. Adanya dua ajaran yang saling berebut kedudukan sebagai ajaran yang paling benar ini menimbulkan pergolakan diantara keduanya. Konflik ini akhirnya diselesaikan dengan memasukkan Budha diantara kedewaan. Dan ajaran Budha diterima sebagai bagian dari ajaran Brahma. Bukti dari bersatunya dua ajaran ini adalah dengan adanya motif-motif Shiwa-Budha dalam candi Budha, juga dengan dibangunnya candi Shiwa-Budha. Meskipun akhirnya dikemudian agama Budha terpecah menjadi dua golongan.

Sebenarnya sebelum datangnya ajaran Budha, dalam tubuh ajaran Brahmanisme sendiri terjadi konflik. Hal ini karena jumlah dewa yang lebih dari satu dan setiap tempat mempunyai dewa yang disembah, seperti daerah pegunungan yang mengharap curah hujan yang banyak, mereka memuja dewa Rudra. Pemuja dewa Shiwa meyakini dewa Shiwa yang paling utama. Adapun pemuja dewa Brahma menganggap dewa lain hanya pelaksana. Disinilah muncul konflik dewa siapa yang paling utama. Dan pada akhirnya disepakati penggabungan ketiga dewa tersebut dalam satu kedewaan yang dikenal dengan Trimurti, yakni tiga unsur kedewaan yang digambarkan dalam arca satu tubuh dengan tiga wajah. ${ }^{4}$

Setelah pergolakan terselesaikan, tanah Jawa kedatangan orangorang Majusi yang terusir dari Timur Tengah, yakni ketika terjadi penaklukan Dinasti Islam atas Imperium Persia. Orang Majusi berlaku sebagaiman orang Hindu namun sebagai penyembah api dan bendabenda langit, mereka mempengaruhi agama Hindu dengan macam-

\footnotetext{
${ }^{3}$ Ibid., 5

${ }^{4}$ Dono Sunardi, Mengislamkan Jawa; Sejarah Islamisasi di Jawa (Jakarta: PT. Serambi Ilmu Semesta, 2013), 8-9.
} 
macam ilmu perbintangan, perhitungan keberuntungan dan kesialan berdasarkan zodiak, macam-macam ilmu hitam dan magis. ${ }^{5}$

Lambat laun terjadi penyatuan antara ajaran-ajaran ini. Pada mulanya ajaran Hindu yang menyatu dengan ajaran Majusi terlebih dahulu. Hingga tidak ada perbedaan sama sekali antara ajaran Majusi dan Hindu, bahkan nama Majusi seakan lenyap. Masyarakat hanya mengenal ajaran yang telah tercampur ini sebagai ajaran Hindu. Oleh karena itu banyak ajaran Hindu ditanah Jawa yang jika diamati lebih jauh menyerupai kebiasaan orang Majusi, contohnya kebiasaan perhitungan tanggal lahir untuk menentukan sebuah pernikahan, perhitungan lahir yang mempengruhi sial mujurnya seseorang, dll.

Seperti halnya ajaran Hindu dan Majusi, penganut kepercayaan Budha pun melakukan penyatuan kepercayaan menjadi satu dalam kepercayaan Hindu-Budha. Menurut pandangan umum dua ajaran ini dianggap satu. Hal ini terbukati dari motif-motif Shiwa yang terdapat dalam candi Budha, serta dibangunnya candi Shiwa-Budha. Unsur-unsur kepercayaan Hindu-Budha yang kental semakin berkembang dan banyak tersisipi kepercayaan Animisme-dinamisme yang bercorak mistik yang dibawa oleh orang Majusi. Sehingga terjadi pemekaran-pemekaran dari kepercayaan asal. Semua tradisi ini dikemudian hari disebut sebagai tradisi Jawa, sebab tempat pertama kali bercokolnya tradisi ini ada dipulau Jawa. Hingga saat ini masyarakat mengenalnya sebagai Tradisi Jawa Kuno.

Setelah adanya penyatuan kepercayaan dari tiga ajaran di Jawa, datanglah ajaran Islam melalui para pedagang Arab. Tak seperti agama sebelumnya, Islam datang dengan cara damai. Islam Jawa menampilkan diri sebagai ajaran yang penuh cinta damai, sesuai dengan kebiasaan masyarakat, tidak mencela kepercayaan lama. Para kalangan bawah disentuh dengan menularkan pengetahuan berniaga, bertani, memberi jasa pengobatan, dan mengusir makhluk halus serta menanamkan kesamaan strata. Para muballigh menempuh cara adaptif dengan membiarkan tradisi yang mengakar kuat, seraya melakukan lagkahlangkah infiltrasi dan pandangan Islam. Aspek doktrin disisipkan melalui gending-gending dan tradisi rakyat. ${ }^{6}$

Wali Songo adalah contohnya, mereka sebagai sosok-sosok pembawa bendera Islam ditlatah tanah Jawa. Melalui kedalan batin mereka, keluasan berpikir mereka, ketegaran lembah himmah mereka, dan kejernihan embun tutur mereka, membuat Islam datang penuh kesan, santun, hadir dengan kedamaian dan tentram. Hal ini amat

\footnotetext{
5 Ibid., 10.

${ }^{6}$ Ibid., 10
} 
menarik ditengah suasana pengap stratifikasi kasta, mitos animisme dan dinamisme yang tak menyediakan ruang berpikir dan berkembang. Hingga pada akhirnya, rakyat Jawa berbondong-bondong masuk Islam.

Para wali tidak menyerukan pemberhangusan tradisi, akan tetapi intensif mengajarkan tauhid melalui cara apa saja seperti membuka pesantren, dakwah keliling, menciptakan media hiburan dan seni dakwah. Dengan cara bijaksana, penuh telaten, dan keuletan para wali mengakrabkan ajaran Islam melalui langkah Jawaisasi, atau dengan karyakarya seni yang santun dan ramah. Selebihnya para muballigh ini lebih banyak mentolerir kekeliriuan yang tidak fatal dengan terus membenahi sedikit demi sedikait guna menjaga perasaan masyarakat yang sensitif. Ada sebuah prinsip dasar dalam cara mendidik masyarakat yang disampaikan Imam Al-Ghozali yakni jika orang yang didik tidak mau meninggalkan prilaku rendah sama sekali atau tidak mau mengganti sifat rendah dengan sikap baik yang berlawanan, maka sebaiknya memindahnya dari perilaku tercela pada perilaku tercela lain yang lebih ringan.

Fenomena tradisi Jawa kuno yang berasimilasi dengan Islam ini juga terjadi di Dusun Ngendut, Desa Kesamben, Kecamatan Ngoro, Kabupaten Jombang. Disebuah desa kecil yang dihuni \pm 200 kepala keluarga ini juga memiliki sebuah tradisi yang mereka laksanakan sejak lama. Tradisi ini adalah tradisi Hindu-Budha yang sudah dilaksanakan sejak pertama kali pembabatan lahan hutan yang kemudian menjadi tempat tinggal sekelompok manusia yang dikemudian hari menjadi sebuah dusun yakni Dusun Ngendut. Tradisi tersebut dikenal dengan sebutan "Ruwah Desa".

Umumnya, masyarakat menganggap Ruwah atau Ruwahan adalah tradisi yang biasanya dilaksanakan untuk mengenang dan mengirim doa wafatnya sanak saudara. Ruwah juga sering dianggap sebagai bulan baik untuk perayaan tradisi-tradisi yang bersifat adat, semisal Nyadran, Nayub dan lainnya. Dibeberapa daerah Ruwah bisa juga digunakan sebagai bulan yang digunakan untuk mencuci benda-benda pusaka.

Sedangkan di dusun Ngendut, Ruwah Desa adalah sebuah tradisi yang serupa dengan sedekah desa yang dilaksanakan pada setelah panen besar dilakukan. Tradisi ini dianggap sebagai ucapan terima kasih kepada Tuhan terlebih kepada danyang desa atas panen dan kesehatan yang mereka dapatkan. Acara ini dilaksanakan setiap setahun sekali. Tradisi

\footnotetext{
${ }^{7}$ Ibnu Ismail, Islam Tradisi Studi Komparatif Budaya Jawa dengan Tradisi Islam, (Kediri: Tetes Publishing, 2011), 28.
} 
Ruwah Desa ini berupa acara tasyakuran (kundangan/barian) dimana setiap warga membuat tumpeng. ${ }^{8}$

Setelah acara tasyakuran selesai barulah acara inti dimulai, yakni pagelaran wayang kulit dan ditutup dengan acara tradisional lain. Hampir semua pelaksanaan ruah desa dilaksankan dipemakaman, kecuali pertunjukan penutup. Masyarakat setempat percaya, jika Ruwah Desa dan segala tata caranya tidak dilaksanakan secara lengkap maka akan memunculkan gejala alam yang tidak biasa serta wabah penyakit yang akan meyerang dusun tersebut. Menurut penuturan warga, bertahuntahun silam penduduk dusun pernah absen dalam melaksanakan tradisi ini, dan seperti yang telah di perkirakan, penduduk mengalami gagal panen dan bermunculan hal buruk lain yang menimpa masyarakat dusun ini. $^{\text {? }}$

Dengan uraian diatas, peneliti akan mengadakan penelitian yang berjudul "Tradisi Ruwah Desa Dan Implikasinya Terhadap Pengetahuan Tauhid Masyarakat Dusun Ngendut Desa Kesamben Kecamatan Ngoro Kabupaten Jombang"

\section{Tradisi Ruwah Desa}

Tradisi adalah segala sesuatu yang disalurkan atau diwariskan dari masa lalu ke masa kini atau sekarang. Istilah tradisi secara umum digunakan untuk menunjuk kepada suatu nilai, norma, dan adat kebiasaan yang telah lama dan hingga kini masih diterima, diikuti bahkan dipertahankan. ${ }^{10}$ Tradisi menjadi sesuatu yang sakral dalam kehidupan masyarakat pinggiran terutama masyarakat desa.

Tradisi muncul melalui dua tahap. Pertama, tradisi muncul dari bawah melalui mekanisme kemunculan secara spontan, tidak diharapkan serta melibatkan rakyat banyak. Karena sesuatu alasan, individu tertentu menemukan warisan historis yang menarik perhatian, ketakziman, kecintaan dan kekaguman yang kemudian disebarkan melalui berbagai cara, memengaruhi rakyat banyak. Kedua, tradisi muncul dari atas melalui mekanisme paksaan. Sesuatu yang dianggap sebagai tradisi dipilih dan dijadikan perhatian umum atau dipaksakan oleh individu yang berpengaruh atau berkuasa. ${ }^{11}$

Tradisi Ruwahan salah satunya, tradisi ini muncul tanpa mekanisme paksaan dari orang-orang yang berkuasa. Tradisi Ruwah atau Ruwahan merupakan warisan histori yang telah menarik kekaguman

\footnotetext{
8 Observasi, di Dusun Ngendut Kesamben, 27 Mei 2017.

${ }_{9}^{9}$ Observasi, di Dusun Ngendut Kesamben, 27 Mei 2017.

${ }^{10}$ Imam Bawani, Tradisionalisme (Surabaya: al-Ikhlas, 1993), 23.

11 Piotr Sztompka, Sosiologi Perubahan Sosial (Jakarta: Penerbit Prenada Media, 2010), 12.
} 
bahkan kecintaan bagi masyarakat. Dari kecintaan dan kekaguman inilah akhirnya tradisi ruwah dilaksankan turun temurun dalam kurun waktu yang cukup lama. Ruwah sendiri adalah nama bulan dalam kalender Jawa. Namun nama ini sering dikaitkan dengan serangkaian ritual adat yang dilakukan dibeberapa tempat khususnya di Kepulauan Jawa. Ruwahan sendiri pada umumnya adalah sebuah adat yang dilaksanakan sebagai ucapan terima kasih kepada sang pencipta dan alam.

Ruwah dalam kalender Jawa terjadi pada bulan ketujuh hijriyah. Kata Ruwah sendiri adalah kata serapan dari bahasa Arab "arwah", bentuk plural dari roh. Hal ini disebabkan, ruwah dijadikan sebagai bulan mengenang para leluhur yang sudah meninggal. Penanggalan ini dibuat oleh Sultan Agung Hanyokrokusumo yang merupakan gabungan antara penanggalan Saka dan Hijriyah. ${ }^{12}$

Penanggalan Saka adalah sistem penanggalan Hindu yang didasarkan pada peredaran bumi dalam berevolusi mengelilingi matahari. Permulaan penetapan penanggalan ini bertepatan dengan hari Sabtu tanggal 14 Maret 1978 M, yakni satu tahun setelah penobatan Prabu Syaliwahyono (Aji Soko) sebagai raja India. ${ }^{13}$ Diambil dari nama penggagasnya maka sistem penanggalan ini dikemudian hari disebut dengan penanggalan Saka atau Soko.

Sedangkan penanggalan Islam atau Hijriyah dihitung berdasarkan peredaran bulan mengelilingi matahari. Seperti yang telah disebutkan sebelumnya, terjadi penggabungan dua sistem penanggalan yakni penanggalan Saka dan Hijriyah yang nantinya menjadi sebuah sistem penanggalan baru yakni sistem penanggalan Jawa. Oleh orang Jawa penanggalan Saka digunakan untuk menentukan hari baik dan memulai sebuah kegiatan seperti berdagang. Hal ini terbukti dengan adanya nama pasar sesuai dengan nama pasaran yang dianut seperti pasar Wage, pasar Legi, dan pasar Kliwon. Sedangkan penanggalan Hijriyah digunakan untuk menentukan jadwal-jadwal ibadah dan hari-hari besar umat Islam.

Dalam penanggalan hijriyah, bulan Ruwah dikenal dengan bulan Nisf Sya'ban. Bulan dimana rahmat dan doa terkabul sebab Allah SWT membentang lebar-lebar sifat derma-Nya dengan mengabulkan setiap permintaan dan menerima segala permohonan. Amal seseorang diangkat oleh Allah setiap hari dua kali; setelah subuh dan asar. Sepekan dua kali; hari senin dan kamis, setahun sekali; saat nisf sya'ban. Banyak keutamaan yang terdapat pada bulan nisf sya'ban yaitu diturunkannya rizki, keberuntungan bahkan kesialan.

12 Ibn Ismail, Islam Tradisi Studi Komparatif Budaya Jawa dengan Tradisi Jawa, (Kediri: Tetes Publishing, 2011) 27.

${ }^{13}$ Muh. Hadi Bashori, Penanggalan Islam, (Jakarta: Elex Media Komputindo, 2013), 243. 


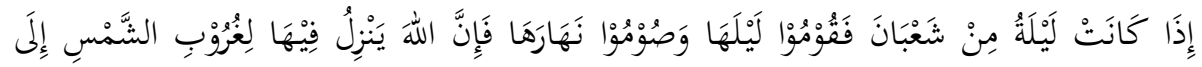

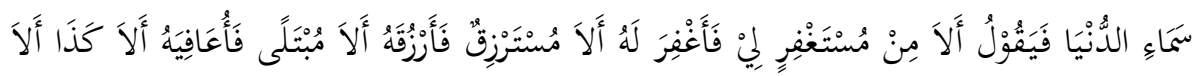 كَذَا حَتَّى يَطْلُعَ الْفَجْرُ}

"Apabila telah datang malam Nishfu Sya'ban, maka beribadablah pada malam harinya dan berpuasalah pada siang barinya, sesunggubnya (rabmat) Allah turun pada malam itu ke langit yang paling bawah ketika terbenamnya matahari, kemudian Allah menyeru "Adakah orang yang meminta maaf kepadaku, maka akan Aku ampuni. Adakah yang meminta rizqi, maka Aku akan melimpabkan rizqi kepadanya. Adakah orang yang sakit, maka akan Aku sembubkan". Dan hal-hal yang lain sampai terbitnya fajar"14

Dalam adat Jawa, ruwahan merupakan tradisi penghormatan kepada leluhur. Menurut kepercayaan, mulai tanggal 15 bulan Ruwah sampai akhir Ruwah, arwah para leluhur kembali ke makam sehingga keluarganya memiliki semacam "kontak sripitual" dengannya. Acara ruwahan yang biasanya dilakukan adalah mengunjungi, merawat, dan membersihkan makam leluhur, menabur bunga atau nyekar di pusara leluhur untuk menciptakan keindahan dan wewangian. Disamping itu sekaligus sebagai tanda penghormatan dan doa agar Allah mengampuni dosa para leluhur. Biasanya diiringi acara selametan dengan membuat makanan berupa ketan, kolak atau apem. ${ }^{15}$

\section{Sejarah Tradisi Ruwah}

Ruwahan di bulan Sya'ban dalam budaya Islam Jawa adalah tradisi yang selalu dilaksanakan sepuluh hari sebelum bulan Puasa (Ramadhan). Hampir tak ada yang tahu persis kapan sebenarnya tradisi ruwahan bagi orang Jawa dilaksanakan untuk pertama kalinya. Namun dalam ajaran Islam, bulan Sya'ban yang datang menjelang Ramadhan merupakan bulan pelaporan atas amal perbuatan manusia. Melaporkan segala daya dan upaya yang telah dilakukan selama setahun, untuk nantinya manusia berintrospeksi.

14 https://generasisalaf.wordpress.com/2015/06/01/dalil-nishfu-syaban-menurutulama-salaf/, diakses tanggal 20 September 2017 pukul 14:22 PM

${ }^{15}$ Fahmi Suaidi dan Abu Aman, Ensiklopedia Syirik dan Bid'ah (Solo: Aqwam, 2012), 158. 
Bagi masyarkat Jawa tradisi atau ritual Ruwahan sudah ada pada zaman Hindu-Budha. Ruwahan bukanlah tradisi asli dari Jawa melainkan peninggalan dari agama Hindu. Pada saat itu ruwahan dikenal dengan tradisi upacara sradha namun kemudian masyarakat Jawa lebih mudah menyebutnya dengan upacara nyadran.

Nyadran sendiri berasal dari kata "sradha" dari bahasa Sansekerta yang artinya keyakinan, percaya atau keparcayaan. Konon Ratu Tribuana Tunggadewi raja ketiga Majapahit ingin melakukan doa kepada sang ibunda Ratu Gayatri, dan roh nenek moyangnya yang telah diperabukan di Candi Jabo. Untuk keperluan itu dipersiapkanlah aneka rupa sajian untuk didermakan kepada para dewa. Untuk memeriahkan ia juga membagikan macam-macam hadiah. Sepeninggalnya tradisi ini dilanjutkan oleh Prabu Hayam Wuruk yang kemudian dikenal dengan 'Caddha'. ${ }^{16}$

Di banyak tempat, nyadran lebih akrab disebut besik deso, karena pelaksanaannya tidak lepas dari kerja bakti setingkat RT atau lebih untuk membersihkan makam kampung. Untuk memeriahkan, biasanya setiap keluarga menyiapkan aneka kue dan minuman. Untuk dipakai munjung kepada saudara yang lebih tua, juga merupakan ubarampe kenduri. Makanan sumbangsih masyarakat yang telah siap lalu diletakkan pada jodang atau tandu. Seusai bersih makam (besik), masyarakat sekampung menggelar kenduri yang didahului dengan kirim do'a kepada leluhur di area sepanjang jalan masuk menuju pemakaman atau lahan kosong disekitar makam. Sebagai tanda acara sudah berakhir dibagikan nasi berkat serta berbagai rupa lampai yang berlangsung diperebutkan warga karena dipercaya mengandung berkah. ${ }^{17}$

\section{Pelaksanaan Tradisi Ruwah}

Pelaksaan tradisi ruwah yang oleh penduduk Jawa sering disebut nyadran ini memiliki perbedaan disetiap daerah. Hal ini terjadi karena setiap daerah memiliki alasan filosofi dan historis yang berbeda-beda dimasing-masing tempat. Selain itu, perbedaan dalam pelaksanaan nyadran juga dipengarui oleh keadaan aqidah penduduk di setiap daerah tersebut. Nyadran versi Islam jauh berbeda dengan nyadran versi HinduJawa.

Di Asta Tuju', Gubang Kebondadap Saronggi Sumenep nyadran dilakukan dua kali dalam setahun. Masyarakat Sidomulyo Batu Malang melakukan upacara ke punden-punden desa, petilasan Nyai Mas

\footnotetext{
${ }^{16}$ Ibnu Ismail, Islam Tradisi Studi Komparatif Budaya Jawa dengan Tradisi Islam, 146.

${ }^{17}$ Ibid., 148.
} 
Dongpuro, makam Mbah Ranti, makam Mbah Kalih, yang disebut upacara barikan. Masyarakat Tengger mengenal upacara unan-unan, yakni sajian disanggar punden desa. Semangat memuja pada punden ini juga tercermin dalam adat entas-entas, sedekah bumi, dan nenepi. ${ }^{18}$

Umumnya dalam acara pemujaan, dukun akan menyiapkan kemenyan dan area bunga. Setelah pembakaran kemenyan, dibacakan mantra agar arwah datang bersemayan diarea bunga yang kemudian mereka puja. Masyarakat juga menyiapkan sesaji kue, minuman, dan kesukaan mayit. Selanjutnya sesaji ditata rapi, diberi bunga setaman dan diberi penerangan berupa lampu. Juga dilakukan penyekaran denagn mengirim bunga kepada arwah. Bunga Kantil, Telasih, Kenanga, Melur dan Melati diletakkan diatas nisan. Juga makanan favorit arwah yang diletakkan dikuburan kemudian diadakan pembakaran kemenyan dan merapal doa-doa. ${ }^{19}$

Tradisi pemujaan ini masih dapat dijumpai pada masyarakat abangan. Biasanya untuk menyemarakkan mereka akan mengadakan kesenian tayuban, ludruk, atau jaranan. Pada dasarnya, semangat upacara nyadran adalah pemujaan pada arwah pituo desa atau danyang desa yang berasal dari kepercayaan animism dan dipusatkan pada pusara punden.

Sedangkan dalam versi Islam, nyadran adalah bakti dan hormat pada tetua dengan kirim do'a, gotong royong, silaturrahim untuk mengumpulkan balung pisah, yakni ajang perkenalan trah keturunan moyang desa. Bagi mereka yang pulang dan sukses dirantau, nyadran dikaitkan dengan sedekah pada fakir miskin, membangun tempat ibadah, memugar cungkup dan pagar makam sebagai wujud balas jasa atau pengorbanan leluhur yang sudah mendidik. ${ }^{20}$

Pelaksanaan nyadran dalam versi Islam lebih disesuaikan dengan Islam yakni pada Nisfu Sya'ban, bulan yang dikaruniakan pada Rasulullah SAW yang identik dengan ziarah untuk meminta restu karena akan memasuki bulan Ramadhan. Untuk tempatnya pun diarahkan pada makam tokoh besar yang benyak berjasa dalam syiar agama. Seperti di kabupaten Banyumas, masyarakat melaksanakan nyadran di makam Syekh Muchorodin atau Mbah Agung Mulyo, di Kalidangu Demak nyadran dilaksanakan di makam Sunan Kalijaga, di dusun Panjang Lor kel. Panjang Ambarawa Semarang nyadran dilaksanakan di makam Nyi Tirto Tinoyo atau lebih dikenal sebagai Nyi Panjang. ${ }^{21}$

\footnotetext{
18 Ibid, 147.

${ }^{19}$ Ibid, 148.

${ }^{20}$ Ibid, 149.

${ }^{21}$ Ibid. 149.
} 
Tradisi Nyadran dalam versi Islam jelas berbeda dengan tradisi pemujaan. Meski istilah penyebutan sama, hal ini hanya sebagai langkah agar tradisi terwadahi dalam nama yang njawa. Sekaligus agar lebih diterima sebagai bagian dari budaya Jawa tanpa bertujuan untuk tasyabbuh, yakni agar serupa dengan dengan adat Hindu-Jawa.

\section{Pengetahuan Tauhid \\ Pengertian Pengetahuan Tauhid}

Tauhid berarti keesaan, tauhid sendiri berasal dari bahasa Arab, masdar dari وحد-يوحد yang berarti keesaan (jawa: nyumigiaken). Maksudnya, ittikad atau keyakinan bahwa Allah SWT adalah Esa, tunggal. Pengertian ini sejalan dengan pengertian tauhid yang ada dalam Bahasa Indonesia yakni meng-Esakan Allah. Mentauhidkan berarti menyakini ke-Esaan Allah SWT dan tidak ada sekutu baginya.

Ada beberapa takrif ilmu tauhid menurut ulama', diantaranya sebagai ilmu yang membahas dan melengkapkan segala hujjah terhadap keimanan, berdasarkan dalil-dalil akal serta menolak dan menangkis segala faham aliran bid'ah yang keliru. Yang menyimpang dari jalan yang lurus. Takrif yang pertama ini membahas segala hal tentang keimanan, ketuhahan, kerasulan, soal-soal ghaib lainnya, malaikat dan akhirat. Dan mencakup tiga hal lainnya yakni, Ilahiyat (ketuhanan), Nubuwat (kenabian), sam'iyat (keakhiratan dan malaikat). ${ }^{22}$

Ilmu yang selanjutnya adalah ilmu yang membahas tentang wujud Allah, sifat-sifatnya meliputi sifat yang wajib di-ishbathkan baginya, sifatsifat yang harus baginya (mumkin) dan sifat-sifat yang wajib ditolak. Juga tentang rasul-rasul untuk membuktikan dan menetapkan kerasulan. ${ }^{23}$ Takrif yang kedua ini membahas tentang kerasulan dan ketuhanan saja.

Dalam perspektif lain Tauhid adalah sikap meyakini keesaan Allah dalam rububiyah. Ikhlas beribadah kepadanya, serta menetapkan baginya nama-nama dan sifat-sifatnya. Tauhid rububiyah (mengesakan Allah dalam segala perbuatan) dapat diaplikasikan dengan meyakini bahwa dia sendiri yang menciptakan segenap makhluk. Seperti yang disebutkan dalam Al-Quran surat Az-Zumar ayat 62: ${ }^{24}$

Allah menciptakan segala sesuatu

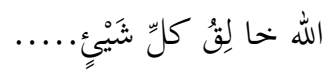

\footnotetext{
22 Teungku Muh. Hasbi Ash Shiddiqie, Al-Islam, (Semarang: Pustaka Rizki Putra:, 1998). 107

${ }^{23}$ Ibid., 107

${ }^{24}$ Shalih Bin Fauzan, Kitab Taubid, Terj. Agus Haan Bashori (Jakarta: Darul Haq, 2012), 19
} 
Jadi pendidikan Tauhid adalah atau pondasi awal manusia membangun moral dan intelektual agar dapat berperan sebagaimana yang dituntunkan dalam syariat yakni hanya mengesakan Allah tanpa membuat persekutuan bagiNya.

\section{Macam-macam Tauhid}

Tauhid dibagi menjadi tiga macam, diantaranya adalah: Taubid Ulubiyyah, Taubid Rububiyyah, dan Taubid Asma' wa Shifat.

a) Tauhid Uluhiyyah

Tauhid Uluhiyyah adalah mengesakan Allah SWT, mendekatkan diri kepadaNya, eperti berdoa, rasa takut (khauf), berharap (raja'), pengorbanan dalam arti penyembelihan hewan (dzabh), memohon pertolongan (isti'anah), meminta perlindungan (isti'adzah) dan segala macam yang disyariatkan dan diperintahkan Allah Azza wa Jalla, tanpa menyekutukan-Nya dengan sesuatu apa pun. ${ }^{25}$ Allah tidak akan ridha bila dipersekutukan dengan sesuatu apapun. Bila ibadah dipalingkan kepada selain Allah, maka pelakunya akan jatuh pada syirik yang besar dan tidak akan diampuni dosanya apabila dia mati dalam keadaan tidak bertaubat kepada Allah atau perbuatan syirik. Dalam QS. An Nisa: 48

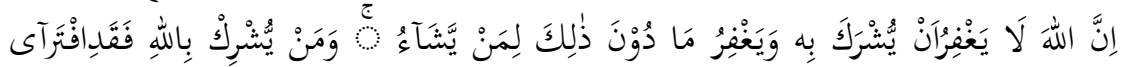

إِتًْاً عَظِْيمًا

b) Tauhid Rububiyyah

Tauhid Rububiyyah berarti mentauhidkan segala sesuatu yang dikerjakan Allah SWT, baik menciptakan, memberi rizki, menghidupkan dan mematikan. Allah adalah Raja, Penguasa dan Rabb yang mengatur segala sesuatu. ${ }^{26}$ Allah SWT berfirman dalam QS Al-A'raaf: 54

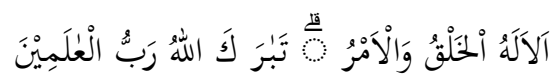

c) Tauhid Asma' wa Shifat

Ahlu Sunnah telah menetapkan Nama-nama maupun Sifat-sifat Allah SW'T dan mencsucikanNya dari segala aib dan kekurangan, sebagaimana telah disucikan oleh Allah dan Rasul-Nya. Wajib bagi kita untuk menetapkan Sifat-Syafi'i tauhid Asma' wa Shifat adalah beriman pada Allah dan kepada apa-apa yang datang dari Allah sesuai dengan apa yang dimaksud oleh Allah dan beriman kepada

\footnotetext{
${ }^{25}$ Syarif Hidayatullah, Ensiklopedia Rukun Islam, (Jakarta: Al-Kautsar Prima, 2008), 53.

${ }^{26}$ Ibid, 55.
} 
Rasulullah dan kepada apa-apa yang datang dari Rasulullah, sesuai dengan apa yang dimaksud oleh Rasulullah. ${ }^{27}$ Firman Allah SWT:

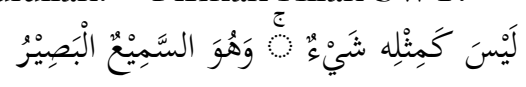

Maksud dari kalimat "Tiada sesuatu pun yang serupa denganNya", adalah bantahan untuk orang-orang yang menyamakan Sifatsifat Allah dengan Sifat-sifat makhluk. Sedangkan kalimat "Dan Dia Maha Mendengar lagi Maha Melihat" juga merupakan bantahan untuk orang-orang yang mengingkari Sifat-sifat Allah.

\section{Cara Mengembangkan Pengetahuan Tauhid}

Aktivitas pengetahuan Islam pada dasarnya adalah menjadi tanggung jawab setiap orang Islam dan untuk menemukan konsep pendidikan Islam ideal adalah tangung jawab moral bagi setiap pakar muslim untuk membangun teori Islam sebagai paradigma ilmu pengetahuan. Islam dengan ajaran tauhidnya sebagai paradigma pendidikan mempunyai karakteristik yang berbeda dengan paradigmaparadigma lainnya yang mendasari konsep pendidikan. Pendidikan adalah faktor penting dalam sebuah eksisitensi sebuah peradaban. Bahkan, bisa dikatakan pendidikan adalah hal yang tidak bisa dilepaskan dari kehidupan.

Untuk membangun sebuah peradaban, dapat dimulai dari generasi penerus umat, dan generasi penerus umat yang dimaksud adalah anak. Didalam Islam sendiri pentingnya pendidikan terhadap anak mendapatkan porsi yang besar. Hanya saja mayoritas masyarakat masih belum memahami perihal prioritas pendidikan anak dalam Islam. Kebanyakan orang tua dan pendidik baru memprioritaskan sisi pendidikan yang bersifat duniawi.

Maksud dari tanggung jawab pendidikan Islam pada anak ini dikerucutkan pada pemahaman tentang iman. Pendidikan iman adalah mengikat anak dengan dasar-dasar keimanan, rukun Islam dan dasardasar syariat semenjak anak mulai mengerti dan memahami. Cara-cara yang dapat dilakukan untuk mamahamkan anak pada dasar-dasar iman, rukun-rukun Islam, dan hukum sariat dapat dimulai sedini mungkin, diantaranya dengan membuka kehidupan anak dengan kalimat tauhid, mengajarkannya masalah halal dan haram setelah ia berakal,

\footnotetext{
${ }^{27}$ Ibid, 56.
} 
memerintahkannya untuk beribadah saat umur tujuh tahun, mendidik untuk cinta pada Nabi, keluarganya, dan cinta membaca al-Quran. ${ }^{28}$

Telah disepekati bahwa seorang anak dilahirkan diatas fitrah tauhid, akidah keimanan kepada Allah, berdasarkan kesuciannya. Jika ia disuguhi pendidikan didalam rumah yang baik, suasana sosial yang baik, dan lingkungan belajar yang aman. Maka nantinya anak akan tumbuh diatas keimanan yang kuat.

Namun hal ini tak lantas menjadikan manusia yang telah dewasa dan masa kecilnya tidak mendapatkan bimbingan tauhid dan syriat Islam lepas dari kewajiban mempelajari dan mengembangkan ketauhidan dalam dirinya.

Semua orang berkewajiban untuk menumbuhkan iman dalam dirinya dengan berbagai cara yang bisa ditempuh. Mungkin dari tingkat yang sederhana, kemudian berkembang dan terus berkembang menuju kesempurnaan, itu berarti iman menuntut perjuangan terus-menerus tanpa berhenti. ${ }^{29}$

Tingkat sederhana dalam bertauhid yakni bahwa seorang mukallaf harus mengetahui apa-apa yang menjadi hak-hak Allah dan apa yang menjadi kewajibannya terhadap hak-hak tersebut. Hak Allah atas makhluknya adalah mengesakan, menyembah dan mengabdi kepada-Nya dan tidak menyekutukan selain-Nya, sesuatu yang tergambar dalam manifestasi dari kalimat Laa ilaha illallah.

Makna dari syahadat adalah pengakuan tauhid kepada dzat Allah. Maka dari itu memahami makna dari Laa ilaha illallah adalah wajib atas setiap muslim. Selain itu ilmu tentang Laa ilaha illallah adalah ilmu yang paling agung yang dapat menyelamatkan manusia dari ancaman kengerian di hari kiamat. ${ }^{30}$ Selain itu sesungguhnya dengan tauhid, keyakinan dan kepercayaan manusia akan lebih mantap dan meningkat untuk mengakui bahwa Allah adalah yang satu yang hak untuk disembah. Dengan keyakinan yang kuat ini akan kemaha kuasaan dan keesaan Allah, manusia bisa selamat bahagia di dunia dan di akhirat.

Pemahaman tauhid dapat dibentuk dengan peran pendidikan dalam menciptakan dan mendorong peserta didik untuk melakukan kebaikan. Setiap muslim percaya bahwa ganjaran yang baik adalah kebaikan dan sebaliknya ganjaran perilaku jahat adalah berupa kejahatan. Jadi peran pendidikan tidak hanya proses transformasi ilmu duniawi saja akan tetapi pendidikan terdapat landasan tauhid juga. Selain itu diajarkan

\footnotetext{
28 Abdullah Nashih 'Ulwan, Tarbiyatul 'Aulad fil Islam, terj. Arif Rahman Hakim (Solo: Insan Kamil, 2013), 111-112.

${ }^{29}$ Nurcholis Madjid, Pintu-Pintu Menuju Tuban, (Jakarta: Penerbit Paramadina, 2004), 7.

${ }^{30}$ Syarif Hidayatullah, Ensiklopedia Rukun Islam, 2-3.
} 
pula pada peserta didik bahwa kehidupan ini tidaklah berakhir di dunia saja lebih jauh ada kehidupan yang lebih kekal abadi, sehingga dunia adalah tempat untuk mencari bekal bagi kehidupan akhirat.

\section{Dampak Tradisi Ruwah pada Masyarakat}

Bangunan tradisi adalah ikhtiar manusia yang berangkat dari tata norma dan spiritual masyarakat. Tampilan lahirnya akan menyesuaikan dengan tingkat pemahaman akidah yang dimiliki. Nilai eksontris inilah yang meruang dibatin inilah yang amat vital selaku pembentukan tradisi. Jika ruang bathin telah diisi dengan tauhid (monotheis) maka unsurunsur tasyrik (politheis) yang seperti mitos, pendewaan dan semacamnya akan tergusur seiring berkembangnya pemahaman pada ajaran tauhid. ${ }^{31}$

Tradisi masyarakat sendiri dibedakan menjadi dua bentuk, yakni tradisi baik dan tradisi buruk. Disebut tradisi baik jika tradisi tersebut tidak bertentangan dengan prinsip-prinsip ajaran Islam. Adapun tradisi buruk, yang oleh karenanya harus ditinggalkan, jika bersifat sebaliknya. ${ }^{32}$ Termasuk tradisi Jawa yang baik sehingga wajib dilestarikan dalam konteks kemasyarakatan adalah sungkem dan andap asor terhadap kedua orang tua. Secara umum sungkem merupakan tradisi Jawa yang dilakukan untuk memohon do'a restu orang tua. Setiap anak Jawa sejak kecil dididik untuk melakukan sungkem kepada orang tua dalam keluarganya.

Jawa sebagai sebuah pulau yang dikenal dengan tradisi yang mengakar kuat dalam kehidupan masyarakat mempunyai cerita menarik dalam setiap pelaksanaannya. Beberapa tradisi yang menarik, seperti ruwatan, maulidan, megengan, ruwah desa, dan lain-lain dapat ditemukan dalam kehidupan masyarakat Jawa, khususnya Jawa Timur dan Jawa Tengah. Dalam setiap tradisi mempunyai tujuan tersendiri serta mempunyai riwayat sosial-historis yang berbeda disetiap daerah.

Tradisi-tradisi tersebut sebagian mempunyai latar belakang mistis yang dibawa dari keyakinan Hindu-Budha dan masyarakat sekarang tetap melaksanakan karena meneruskan apa yang dilakukan pendahulu mereka. Tradisi berlatar belakang keyakinan Hindu-Budha seperti pemujaan pada alam dan bintang, persembahan dengan macam-macam sesaji, meyakini saat-saat sial dan mujur, meyakini hal ghoib sebagai pencipta adalah

\footnotetext{
${ }^{31}$ Ibn Ismail, Islam Tradisi Studi Komparatif Budaya Jawa dengan Tradisi Jawa (Kediri: Tetes Publishing, 2011), 27.

32 Imam Muhsin, Al-Quran dan Budaya Jawa dalam Tafsir al-Huda karya Bakri Syahid, (Yogyakarta: Elsaq Press, 2013), 151.
} 
praktik nyata dari pengkultusan leluhur yang memang menjadi ciri khas orang Jawa.

Hal tersebut memberi celah yang cukup besar untuk setan semakin memperkokoh ikrar sesatnya untuk menyesatkan manusia seperti janjinya. Setan atau jin berperan dalam alam bawah sadar, bisa membuat kesurupan, benda jadi keramat, lingkungan menjadi wingit dan macammacamnya. Sehingga mnusia yang lemah dan bodoh akan digiring untuk memuja-muja, meminta jasa bahkan meninggalkan Tuhan semesta, mengikuti fatwa dukun dialam nyata. Jadi mitos dan gugon tuhon adalah hasil persekongkolan dukun dan para dukun peramal untuk menyesatkan manusia. $^{33}$

\section{Tradisi Ruwah Desa di Dusun Ngendut}

Tradisi ruwah desa di dusun Ngendut adalah tradisi yang dilaksanakan warga sebagai ucapan terima kasih pada alam dan roh leluhur terutama pada danyang desa yang telah memberikan keberkahan berupa hasil panen, kesehatan serta ketentraman. Ritual inti dalam ruwah desa adalah pertunjukan wayang kulit di dalam pemakaman yang sekaligus sebagai acara pembuka, lalu dilanjutkan acara kesenian lain sebagai acara selingan dan ditutup dengan pertunjukan wayang kulit lagi sebagai acara penutup. Ada beberapa hal-hal wajib yang harus ada dalam Ruwah desa selain pertunjukan wayang kulit, yakni tumpeng, kenduri, ujub, kembang boreh dan lain sebagainya.

Ruwah Desa atau yang biasa dikenal dengan nyadran adalah tradisi yang berakar pada kepercayaan masyarakat Jawa ketika masih memeluk Hindu, Budha atau animisme dan dinamisme. Ketika itu sadranan atau ruwahan merupakan pemujaan pada arwah leluhur yang telah meninggal dunia, sekaligus permintaan kepada arwah untuk keselamatan orangorang yang masih hidup didunia. Hal ini tidak terlepas dari kepercayaan bahwa orang yang meninggal masih berpengaruh meskipun telah berada dialam gaib.

Ruwah Desa bagi warga yang hidup di dusun Ngendut merupakan tradisi yang mustahil untuk ditinggalkan. Tradisi peninggalan nenek moyang ini memendam nilai-nilai kearifan lokal yang menjadi ciri khas orang Jawa tulen yang sulit ditemukan dalam kebiasaan modern yang saat ini semakin meluas. Meski dalam pelaksaaan saat ini tidak seramai zaman dahulu, namun tradisi ini tetap menjadi tradisi primadona bagi warga

\footnotetext{
${ }^{33}$ Ibn Ismail, Islam Tradisi Studi Komparatif Budaya Jawa dengan Tradisi Jawa.,16.

${ }^{34}$ Fahmi Suwaidi dan Abu Aman, Ensiklopedia Syirik dan Bid'ah Jawa, (Solo: Aqwam), 131.
} 
Ngendut, mengalahkan tradisi-tradisi dalam perayaan Idul Fitri yang umumnya menjadi tradisi kebanggaan orang-orang muslim.

Berdasarkan wawancara dan dokumentasi yang telah dilakukan oleh peneliti, dapat diketahui bahwa tradisi ruwah desa di dusun Ngendut adalah tradisi yang menarik, nilai positif dari tradisi ini adalah kearifan budaya yang menjunjung tinggi norma, gotong royong serta rasa berbagi dengan sesama. Meski unsur tasyrik masih memenuhi segala aspek pelaksanaan ruwah desa. Tidak dapat dipisahkannya unsur tasyrik ini memang menjadi ciri khas kepribadian orang Jawa yang begitu patuh pada pesan orang tua dan leluhur.

Orang Jawa mempunyai keteguhan memegang wejangan-wejangan serta prinsip hidup dari para leluhur. Terikat secara emosi dengan latar sejarah, mewarisi budayanya dan mengimani sabdanya. ${ }^{35}$ Secara psikologis, iklim daerah katulistiwa yang stabil ini membawa pengaruh pada pembawaan orang Jawa, yakni perasa, peka, naluri kebersamaan tinggi, mendahulukan orang lain dan tidak suka konflik. ${ }^{36}$

Para pendatang didusun Ngendut yang awalnya kurang setuju dengan tradisi ini, akhirnya berubah dan ikut melaksanakan tradisi ini layaknya penduduk setempat. Seperti umumnya sikap orang Jawa yang peka terhadap naluri kebersamaan, para pendatang perlahan mulai mengikuti apa yang dilakukan oleh sebagaian besar orang-orang disekitarnya. Orang-ornag pendatang ini jelas akan merasa sungkan jika tidak ikut melaksanakan ruwah desa.

Orang Jawa dikenal memiliki pembawaan yang sentimentil (perasa), sensitif (peka), punya naluri kebersamaan, mendahulukan orang lain dan tidak suka konflik. Dalam pepatah Jawa disebutkan "Dedalani guna lan sekti, kudu andap asor, wani ngalah duwur wekasane" yang berarti usaha menuju kesuksesan itu harus ditempuh dengan rendah hati, berani mengalah, pada akhirnya akan mendapat kemuliaan. Dampak negatif dari prinsip dasar ini adalah munculnya bangunan etika-sosial yang berpedoman pada kesopanan yang bersifat kepura-puraan, mimik dan kamuflase, kurang percaya diri dan tidak punya egosentris yang kuat. Sehingga untuk menilai kebenaran lebih dominan memakai perasaan (sense). Ada Pepatah "rubub-rubuh asem," mana yang menjadi kecondongan orang banyak, itu yang diikuti. ${ }^{37}$

Dalam menentukan pelaksanaan ruwah desa masyarakat dusun Ngendut berpegangan pada perhitungan berdasarkan masa panen.

\footnotetext{
35 Ibn Ismail, Ibn Ismail, Islam Tradisi Studi Komparatif Budaya Jawa dengan Tradisi Jawa, (Kediri: Tetes Publishing, 2011), 14.

${ }^{36} \mathrm{Ibid}, 15$.

${ }^{37}$ Ibid, 15.
} 
Penentuan pelaksanaan ini jelas berbeda dengan kebiasaan orang Jawa pada umumnya, dimana pelaksanaan ruwahan dilaksanakan pada bulan Ruwah atau bulan Sya'ban. Masyarakat Jawa memang tidak hanya memakai satu sistem penanggalan. Ada beberapa sistem penanggalan yang dipakai masyarakat, seperti sistem penanggalan Masehi, Hijriyah, dan kalender Jawa atau Saka.

Secara astronomi, kalender Jawa dan Masehi tergolong mathematical calendar, sedangkan kalender hijriyah astronomical calendar. Mathematical atau aritmatical merupakan sistem yang didasarkan pada perhitungan matematika. Adapun astronomical calendar berdasarkan fenomena alam. ${ }^{38}$ Biasanya masyarakat Jawa memilih salah satu penanggalan tersebut dalam menentukan waktu yang dianggap hari baik untuk pelaksanaan tradisi-tradisi yang menjadi agenda rutin masyarakat atau ketika masyarakat akan melakukan suatu hajat.

Sistem penanggalan yang dipakai masyarakat dusun Ngendut jelas berbeda dengan penanggalan yang umumnya dipakai masyarakat Jawa. Masyarakat dusun Ngendut memakai sisitem perhitungan yang tidak ditemukan dalam perhitungan manapun, warga dusun memakai penanggalan berdasarkan masa panen. Hal tersebut berdasarkan pada tujuan Ruwah Desa adalah sedekah desa dan wujud rasa syukur atas kesehatan dan hasil panen. Karena Ruwah Desa berhubungan dengan panen maka tradisi tersebut pun dilaksanakan sesudah masa panen.

\section{Keadaan Pengetahuan Tauhid di Dusun Ngendut}

Sesuai dengan penelitian yang dilakukan peneliti, keadaan pendidikan tauhid di dusun Ngendut belum sepenuhnya sejalan dengan akidah. Dalam keseharian, penduduk masih terikat kuat dengan hal-hal mistis yang telah diciptakan dan diwariskan oleh leluhur. Kejadiankejadian diluar nalar yang kerap menimpa orang-orang yang meremehkan wilayah dusun, pemakaman dusun atau tradisi-tradisi yang dilaksanakan warga dusun, memperkuat keyakinan warga dusun Ngendut atas kekuasaan danyang dalam mengatur kehidupan manusia dan mengendalikan alam.

Tradisi Ruwah desa dan kebiasaan masyarakat yang mempercayai danyang desa dan hal-hal supranatural lainnya, membuat warga dusun Ngendut dikenal dengan istilah masyarakat abangan. Abangan adalah istilah untuk menyebut individu atau kelompok yang minim pengetahuan agama dan memegang teguh lakon tradisi yang sering kali mengarah pada tindakan musyrik atau kepercayaan singkretisme.

\footnotetext{
${ }^{38}$ Muh. Hadi Bashori, Penangggalan Islam, (Jakarta: PT.Elex Media Komputindo, 2013), 250.
} 
Beberapa ihtisar kepercayaan singkretisme khas Jawa yang kerap ditemui masyarakat abangan, diantaranya:

1. Pemujaan pada benda alam dan binatang seperti. Disamping arca dan wayang benda-benda juga mereka puja, seperti : gua, hutan, pohon, rawa, sumur, danau, sungai, air terjuan, mata air, keris gong, binatang. Benda alam ini biasa mereka sebut kiyai untuk penghormatan. Seperti tombak Kyai Pleret.

2. Persembahan dengan macam-macam sesaji. Ada kalanya untuk menyenangkan roh, dewa-dewa, bidadari, dan arwah orang yang dihormati, untuk mengusir sial.

3. Meyakini sial mujur berdasarkan tanda, hitungan, pelanggaran mitos.

4. Percaya pada macam-macam roh, ada banyak macam roh menurut orang Jawa dan dikumpulkan dalam tiga macam. Satu, roh alam yaitu setan dan iblis. Dua, roh suruhan atau kiriman seperti jin, memedi, perewangan. Ketiga, roh penasaran dan gentayanagn yakni jiwa, nyawa, dan sukma. Orang Jawa percaya roh bisa berpindah pada binatang dan pada orang.

5. Simbolisasi tradisi, tradisi menjadi bagian dari ajaran keluhuran susila, falsafat hidup dan pesan halus, dll. ${ }^{39}$

Ketauhidan penduduk Ngendut masih dipengaruhi oleh hal-hal seperti kepercayaan pada roh-roh, pemujaan pada arwah leluhur, dan lainnya. Dari hal tersebut maka bisa dikatakan ketauhidan warga masih menempati urutan kesekiannya, karena urutan pertama masih ditempati kepercayaan lama yang masih menganggap adanya kekuatan lain selain Allah. Meski warga dusun tercatat sebagai orang-orang muslim secara menyeluruh. Percampuran tersebut membuat warga dusun nampak seperti orang yang tidak konsisten dengan ajaran Islam.

Orang Islam yang kurang konsisten dalam mengamalkan ajaran Islam menimbulkan anggapan bahwa orang tersebut hanya seorang muslim keturunan. ${ }^{40}$ Muslim keturunan adalah sebutan untuk seseorang yang lahir dari orang tua yang muslim, dan selama menjalani hidupnya berada dilingkungan orang tua, maka dipastikan bahwa orang tersebut dalam keadaan Islam. Meskipun sebenarnya, permasalahan ketauhidan bukan pada status muslim keturunan atau bukan keturunan, namun pada kurangnya mendalami ajaran agama, sehingga kurang perduli dengan aturan-aturan yang telah ada dalam ajaran agama.

Persoalan muslim keturunan yang kurang mendapat ajaran agama, sering kali dianggap sebagai sebab penyimpangan-penyimpangan

\footnotetext{
${ }^{39}$ Ibnu Ismail, Islam Tradisi Studi Komporatif Budaya Jawa, 13.

${ }^{40}$ Syarif Hidayatullah, Ensiklopedia Rukun Islam, 85.
} 
yang ada. Entah dalam bersikap, bermasyarakat, berbudaya, terlebih bertauhid. Muslim keturunan yang semacam ini seperti warna abu-abu diantara pertemuan warna putih dan hitam, tidak bertauhid yang kaffah dan tidak kejawen yang tulen. Warna abu-abu ini menjadi indikator keberadaan sifat tasyik dalam label muslim yang dimiliki.

Banyak indikator penyebab sikap masyarakat yang lebih condong kearah musyrik, diantaranya adalah,

1. Kejumudan, kejumudan adalah kondisi dimana orang menganggap kebenaran adalah sabda brahma atau orang linuwih, sehingga mitos-mitos langsung diserap dan dipercaya.

2. Pengkultusan leluhur, yaitu keteguhan memegang wejanganwejangan serta prinsip hidup dari para leluhur, mewarisi budaya dan meng-imankan sabdanya.

3. Penilaian banyak orang, dimana orang akan mengikuti sesuatu hal yang diikuti oleh banyak orang. Dan yang terakhir adalah campur tangan dukun dan syetan, dukun sebagai penyambung lidah jin yang membuat premis-premis dan berkembang menjadi doktrin, sedangkan kekuatan jin yang setiap saat ia keluarkan menjadi linuwih bagi pandangan orang awam. ${ }^{41}$

\section{A. Implikasi Tradisi Ruwah Desa pada Pengetahuan Tauhid masyarakat dusun Ngendut.}

Tradisi Ruwah Desa didusun Ngendut adalah sebuah tradisi yang sarat akan unsur-unsur mistis. Pengaruh Ruwah Desa yang cukup kuat sudah dipastikan menjadi dasar mengapa pendidikan ketauhidan lemah di wilayah tersebut. Ruwah desa pun bisa disebut sebagai sajen dalam bentuk raksasa. Seluruh ritual-ritual yang tersusun didalamnya memiliki tujuan utama yakni sebagai persembahan kepada danyang.

Seperti yang telah disebutkan bahwa tradisi tradisi ruwah pada mulanya adalah tradisi Hindu-Budha yang oleh orang Jawa dikulturasikan dengan ajaran Islam. Jejak akulturasi ini dapat dilihat dari penyebutan istilah-istilah lokal yang dipakai untuk menyebut hal-hal seperti Tuhan, sembahyang, surge. Masyarakat lebih terbiasa dengan istilah ini daripada istilah dalam bahasa Arab. ${ }^{42}$

Umumnya ruwahan dalam adat Jawa memang menjadi ritual penghormatan kepada leluhur. Acara ruwahan pun seputar mengunjungi, membersihkan makam leluhur, menabur bunga untuk menciptakan keindahan. Acara ruwahan ini juga sebagai tanda penghormatan dan doa

\footnotetext{
${ }^{41}$ Ibnu Ismail, Islam Tradisi Studi Komporatif Budaya Jawa, 14-15.

${ }^{42}$ Imam Bawani, Tradisionalisme (Surabaya: al-Ikhlas, 1993), 23.
} 
agar Allah mengampuni dosa leluhur. ${ }^{43}$ Bukan sebagai ritual pemujaan dan persembahan yang mengesampingkan keberadaan Allah yang berkuasa atas kepemilikannya terhadap dunia.

Tradisi ruwah desa yang menjadi tradisi penting bagi warga ini dan segala hal yang berhubungan dengan keyakinan terhadap arwah leluhur, membuat masyarakat terlihat susah membedakan antara tradisi dan tauhid. Sebagian dari warga sepertinya tidak tahu, sebagian lagi sepertinya tidak perduli, bahwa apa yang mereka lakukan seperti mendatangi sumur yang dianggap tempat bersemayam danyang desa untuk meminta keselamatan dan perlindungan adalah sebuah pelaggaran dalam berakidah, terutama warga yang berusia lanjut. Menjelaskan kesalahankesalahan akidah yang dilakukan warga sama dengan mencari musuh didusun ini.

Sebagaimana yang lazim terjadi pada masyarakat di Jawa dengan pengkultusan manusia (dewata, bathara, raja, punden yang dianggap menitis ruh kedewaan pada sebagian manusia). Syaitan datang dengan menawarkan maksud baik dengan alasan yang masuk akal untuk memperoleh kepercayaan, selanjutnya ia menyisipkan pengaruh sesat sedikit demi sedikit, bertahap, nyaris tanpa disadari, hingga umat digiring untuk mengimani kesyirikan secara massal dan tidak mau percaya dan berpikir ketika datang seruan kebenaran. ${ }^{44}$

Al- Quran surat al -An'am ayat 12 menyebutkan:

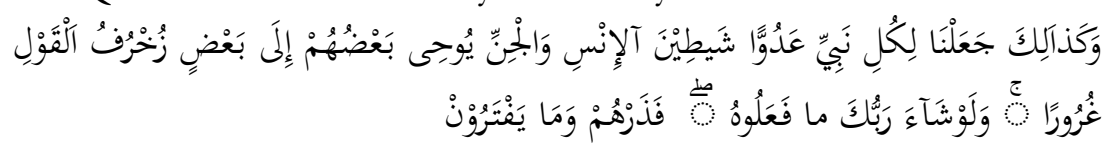

Langkah adaptif yang dilakukan oleh mendiang mudin dusun Ngendut adalah langkah yang cukup berpengaruh merubah kewingitan area pemakaman. Dengan membiasakan membaca tahlil dan yasin dipemakaman yang esok harinya digunakan untuk pelaksanaan Ruwah Desa benar-benar menunjukkan kemanfaatannya. Saat ini area pemakan terlihat rindang dan sejuk layaknya suasana makam yang umumnya terletak ditengan perkampungan, hanya saja nuansa wingit nan menakutkan telah lenyap.

Cara untuk menggeser tradisi klenik yang terlanjur melekat adalah dengan doa-doa pengusir jin sekaligus doa kepada para leluhur. Diantaranya disebut tahlil, dan istighotsah. Tahlil tersusun dari surat mu'awnidzatain, ayat kursi, fatihah, awal dan akhir surat al-Baqoroh, kalimat tauhid, dan lainnya. Sedangkan istighotsah adalah alternatif lain

\footnotetext{
${ }^{43}$ Fahmi Suaidi dan Abu Aman, Ensiklopedia Syirik, 158.

${ }^{44}$ Ibnu Ismail, Islam Tradisi Studi Komporatif Budaya Jawa, 16-17.
} 
selain yasinan guna memohon perlindungan dari gangguan jin dan setan. ${ }^{45}$

Masyarakat dusun Ngendut memang sangat menjaga tradisi Ruwah Desa dan kebiasaan-kebiasaan yang sarat dengan unsur tasyrik denagn begitu kuat, bahkan terkesan tidak dapat dirubah. Namun anggapan tersebut tidak sepenuhnya benar. Dibutuhkan waktu dan kesabaran dalam memperbaiki aqidah. Ada prinsip dasar dalam cara mendidik yang disampaikan Al-Ghozali "Jika orang yang di didik tidak mau meninggalkan perilaku rendah sama sekali atau tidak mau sifat rendah dengan sifat baik yang berlawanan, maka sebaiknya memindahkan dari perilaku tercela pada perilaku tercela lain yang labih ringan.

Maka bila saat ini masyarakat masih tetap dengan kejawenan mereka, maka langkah adaptif untuk menanggulanginya adalah melakukan pendekatan secara halus dan santun. Menuntun masyarakat bahwa tujuan datang ke pesarean dalam perayaan ruwah desa bukan hanya sekedar untuk melakukan tuntutan tradisi, melainkan juga untuk mengingatkan pada diri sendiri bahwa kelak setiap orang akan mati dan dikubur seperti orang-orang yang kini menjadi penghuni makam tersebut. Menunjukkan pada masyarakat bahwa nilai yang terdapat dalam ritual tumpeng yang dibawa ke pemakaman bertujuan untuk menghapus batasan pada siapapun agar mendapatkan kesempatan yang sama untuk mendapatkan rizki, yakni membawa pulang makanan, dimana jika seandainya dilakukan dalam masjid maka tentu akan ada orang-orang tertentu yang enggan atau malu mengikutinya. Entah merasa pakaian yang dipakai tidak pantas, belum membersihkan diri dengan benar, sebelumnya tidak pernah mendatangi masjid sehingga muncul rasa segan atau yang lainnya.

Seperti yang tercantum dalam Q.S. Al-A'raf ayat 199, menyebutkan bahwa:

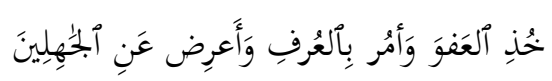

Artinya: Jadilah engkau pemaaf dan surublah orang mengerjakan yang ma'ruf, serta berpalinglah dari pada orang-orang yang bodoh. ${ }^{46}$

\section{Kesimpulan}

Tradisi ruwa desa di dusun Ngendut adalah tradisi serupa dengan sedekah desa. Dalam tradisi terdapat pencampuran unsur religi dengan unsur tradisi Jawa Kuno yang cukup kental. Hampir semua pelaksanaan

\footnotetext{
45 Ibid, 28.

46 Al-Quran dan Terjemahnya (Jakarta: CV. Toha Putra Semarang, 1989)
} 
dalam ritual ruwah desa dilaksanakan didalam pemakaman. Ritual ini perwujudan dari rasa syukur masyarakat kepada Tuhan, alam serta kepada danyang dusun yakni Buyut Sumber Suko yang telah melindungi warga dan lehan pertanian mereka sehingga mereka diberi kesehatan, kemudahan rizki, serta panen yang melimpah. Pendidikan tauhid didusun Ngendut, ketauhidan masyarakat atas keesaan Tuhan semesta alam telah tergeser oleh keyakianan kejawen. Hal tersebut lantaran memang peduduk dusun sangat berpegang teguh pada tradisi kuno sehingga kebutuhan pengetahuan rohani dikesampingkan. Masyarakat lebih memilih datang terlebih dahulu ke sumur pemakaman untuk meminta pertolongan daripada memanjatkan berdoa kepada Sang Khaliq untuk memohon pertolongan. Implikasi tradisi ruwah desa pada pendidikan tauhid masyarakat dusun Ngendut menunjukkan kuatnya pengaruh tradisi ini dalam segala aspek hidup masyarakat. Namun kini telah bermunculan orang-orang yang berperan sebagai penggerak-penggerak dalam kegiatan Islam. Seperti Yasin, Tahlil, dan Sholawatan. Penggerak-penggerak ini umumnya adalah putra-putri dari penggerak-penggerak kegiatan agama yang telah meninggal dan perjuangannya diteruskan oleh anak-anak mereka. Meski perubahan akidah berjalan cukup lambat namun, kemauan orang-orang yang berusaha memasukkan unsur agama dalam ruwah desa patut diapresiasi. Tidak menutup kemungkinan kelak akan muncul generasi baru yang ramah dengan tradisi tanpa keberadaan unsur tasyrik.

\section{DAFTAR PUSTAKA}

Ahmad, Abu dan Cholid Narbuko. Metodologi Penelitian. Jakarta: PT Bumi Aksara, 2009.

Al-Quran dan Terjemahnya. Jakarta: CV. Toha Putra Semarang, 1989.

Arikunto, Suharsi. Prosedur Penelitian Suatu Pendekatan Praktik. Jakarta: Rineka Cipta, 2010.

Ash Shiddiqie, Teungku Muh. Hasbi. Al-Islam. Semarang: Pustaka Rizki Putra, 1998.

Bashori, Muh. Hadi. Penanggalan Islam. Jakarta: PT. Elex Media Komputindo, 2013.

Bawani, Imam. Tradisionalisme. Surabaya: al-Ikhlas, 1993.

Fauzan, Shalih Bin. Kitab Tauhid, terj. Agus Haan Bashori. Jakarta: Darul Haq, 2012. 
Hidayatullah, Syarif. Ensiklopedia Rukun Islam. Jakarta: Al-Kautsar Prima, 2008.

Iskandar. Metodologi Penelitian Pendidikan dan Sosial: Kualitatif dan Kuantitatif. Jakarta: Gaung Persada Press, 2010.

Ismail, Ibnu. Islam Tradisi Studi Komparatif Budaya Jawa dengan Tradisi Islam. Kediri: Tetes Publishing, 2011.

Madjid, Nurcholis. Pintu-Pintu Mепиju Tuban. Jakarta: Penerbit Paramadina, 2004.

Moloeng, Lexy J. Metodologi Penelitian Kualitataif. Bandung: Remaja Rosdakarya, 2002.

Muhsin, Imam. Al-Quran dan Budaya Jawa dalam Tafsir al-Huda karya Bakri Syahid. Yogyakarta: Elsaq Press, 2013.

Mulyana, Deddy. Metodologi Penelitian Kualitatif. Bandung: PT Remaja Rosdakarya, 2010.

Ricklefs, M.C. Mengislamkan Jawa: Sejarah Islamisasi di Jawa dan Penentangnya dari 1930 sampai Sekarang. Jakarta: PT Serambi Ilmu Semesta, 2013.

Saebani, Beni Ahmad. Metode Penelitian. Bandung: CV Pustaka Setia, 2008.

Suaidi, Fahmi dan Abu Aman. Ensiklopedia Syirik dan Bid'ah. Solo: Aqwam, 2012.

Sugiyono. Metode Penelitian Pendidikan. Bandung: Alfabeta, 2013.

Suharjo, Drajat. Metode Penelitian dan Penulisan Laporan Ilmiah. Yogyakarta: UU Press, 2013.

Suharjo, Jamali. Metodologi Studi Islam. Bandung : Pustaka Setia, 2008.

Sunardi, Dono. Mengislamkan Jawa; Sejarah Islamisasi di Jawa. Jakarta: PT. Serambi Ilmu Semesta, 2013.

Suyono. Dunia Mistik Orang Jawa. Jogjakarta: PT. LkiS, 2009.

Sztompka, Piotr. Sosiologi Perubahan Sosial. Jakarta: Penerbit Prenada Media, 2010.

Ulwan, Abdullah Nashih. Tarbiyatul 'Aulad fil Islam. terj. Arif Rahman Hakim. Solo: Insan Kamil, 2013.

Yulis, Rama. Ilmu Pendidikan Islam. Jakarta: Kalam Mulia, 2013. 